\title{
A Study of Compressive, Flexural, Heat Humidity and Heat Transfer of Autoclaved Aerated Concrete Mixed Polypropylene Fiber under Climate of Bangkok
}

\author{
Borvorn Israngkura Na Ayudhya and Peerapol Deshadanuwong \\ Department of Civil Engineering, Rajamangala University of Technology Krungthep, Bangkok 10120, Thailand
}

\begin{abstract}
This paper presents the experimental results of study on mechanical properties, heat and humidity transfer through AAC (autoclaved aerated concrete) mixed with PP (polypropylene fiber). The performance of AAC-PP is investigated in terms of compressive strength, flexural strength, splitting tensile strength, porosity, heat and humidity capacity. The results are compared with control specimen made of autoclaved aerated concrete only (Non-AAC-PP). Results showed that ultimate compressive strength, flexural strength and splitting tensile strength can be obtained when the content of polypropylene fiber added at $0.75 \%$ by volume while porosity of specimens rapidly decreased when content of fiber addition increased above $1 \%$ of its volume. Additional, a comparison study of heat and humidity transfer properties on AAC-PP walls showed that the AAC-PP house had lower indoor air and moisture content than (Non-AAC-PP) house. Therefore, addition PP fiber on AAC increased mechanical properties, enhanced hygrothermal performance and reducing moisture content under tropical climate of Bangkok.
\end{abstract}

Key words: Autoclaved aerated concrete, Non-AAC-PP, polypropylene fiber.

\section{Nomenclature}

\begin{tabular}{|c|c|}
\hline АAC-PP & $\begin{array}{l}\text { Autoclaved aerated concrete walls mixed with } \\
\text { polypropylene fiber }\end{array}$ \\
\hline on-AAC-PP & Non-autoclaved aerated concrete \\
\hline amb & Ambient temperature $\left({ }^{\circ} \mathrm{C}\right)$ \\
\hline wo & $\begin{array}{l}\text { Outside wall temperature of experimental house } \\
\left({ }^{\circ} \mathrm{C}\right)\end{array}$ \\
\hline wi & $\begin{array}{l}\text { Inside wall temperature of experimental house } \\
\left({ }^{\circ} \mathrm{C}\right)\end{array}$ \\
\hline Troom & Inside temperature of experimental house $\left({ }^{\circ} \mathrm{C}\right)$ \\
\hline $\mathrm{Rh}$ & Relati \\
\hline $\begin{array}{l}W \\
d b, d w\end{array}$ & $\begin{array}{l}\text { Humidity }(\mathrm{kg} / \mathrm{kg}) \\
\text { dry bulb globe thermometer and wet bulb glob } \\
\text { thermometer }\end{array}$ \\
\hline & South, north, east, west of experimental house \\
\hline & 1st and 2nd experimental house \\
\hline
\end{tabular}

\section{Introduction}

Energy conservation issue has become a growing social public concern in Thailand since commodity prices have gone up. A problem of heat and humidity enters into house becomes house owner's concern

Corresponding author: Borvorn Israngkura Na Ayudhya, Ph.D., assistant professor, research fields: construction materials, durability of concrete and construction risk. E-mail: borvorn.i@rmutk.ac.th. which increases electricity consumption of household and deterioration of household materials. An excessive heat and high humidity indoor can be occurred by several incidents. For example, high level of heat and moistures enters through building cavities, contact between indoor air and cold surface materials. Excess moisture often originates outside the structure as with foundation drainage problems, or it may be the result of activities by the occupants indoors. Cold surfaces usually are the result of air leakage or inadequate insulation in building cavities, or in rooms where less heat is provided. The high level of heat causes water vapor which creates moist and a different in temperature of two materials cause condensation [1]. Additional, the amount of excess heat and high humidity also increased when intensity of solar radiation hit on the outside wall increased and the duration of hit was longer [2]. The heat normally transfers from outside (high temperature region) to inside (lower temperature region) house by re-emitted process. The heat convection and heat radiation causes 
room temperature and temperature of objects inside the house increases. The transfer of heat appears in the form of sensible heat and latent heat of the objects. This is the result of difference in transferred vapor pressure from higher to lower area [3].

\section{Literature Review}

Thailand is a hot and rather humid tropical country with monsoonal climate. The hot climate caused roof to absorb heat and transfer to house which created an unbearable environment. However, the problem was usually solved by using air conditioner. This caused significantly increase in household electricity consumption by 60\% [4]. Ogoli [5] studied methods of installing thermal insulation in the attic room. He found that plane insulation method was help to reduce in-house temperature. The average inside temperature was $22.4{ }^{\circ} \mathrm{C}$ and the outside was $25.4{ }^{\circ} \mathrm{C}$. Cheng et al. [6] conducted the study on color painting affects wall temperature. He found that darker color had greater tendency in increasing room temperature than lighter color when wall materials were the same. In Thailand, Chantawong et al. [7] studied an affect of color painting on wall temperature. They found that heat capacity of exterior paint color with light gray colored, lily white color and light blue colored affected to house temperature. They further found that light paint color reflected sunlight whereas the darker color absorbed the sunlight. The result of their study showed that the light gray had the best performance as the thermal insulation. The thermal insulation ability was higher than lily white color and light blue color. The humidity and the relative humidity inside of the light gray painted house were lower than lily white and light blue color. Suksongyat et al. [8] conducted an experiment on heat and humidity transferred through the wall of experiment houses under Thailand climate. They found that different kind of materials gave different ability of heat and humidity transfer through masonry materials. There were four kinds of masonry materials studied (brickwork, autoclaved aerated concrete mixed with microfiber, autoclaved aerated concrete mixed with sugar dregs and autoclaved aerated concrete only). The results showed that autoclaved aerated concrete mixed with sugar dregs wall gave the lowest room temperature. It was further found that the rate of heat transferred through the wall was also the lowest among other three masonry materials. Similar results were found from other researchers [9].

The aim of this research was to study heat transfer and humidity in house with AAC-PP and Non-AAC-PP walls under hot humid climate of Bangkok. The study was governed to considerable extent by the presence of wall without mortar on both inside and outside wall condition. This study was adopted from the study of Israngkura $\mathrm{Na}$ Ayudhya et al. [10]. They found that AAC-PP specimen gave higher mechanical performance of the restraint than Non-AAC-PP. Fiber addition helped increase AAC strength and also reduce the cost of cement ratio in mixture. The study was conducted in two experimental houses. Each house has similar volume of $4.05 \mathrm{~m}^{3}$. The normal temperature without air conditioner condition was applied. Therefore, the change in temperature, humidity, humidity inside house and walls temperature can be monitored.

\section{Methodology}

\subsection{Detail of Design Mix}

The cementitious materials used in this study were OPC (ordinary Portland cement) type I, which complied with BS 12:1991 [11] and ASTM C150-92 [12]. All AAC specimens were made by according to TIS (Thailand Industrial Standard) 1505-2541 [13]. The composition of AAC was shown in Table 1. The PP (property of polypropylene) fiber was shown in Table 2.

\subsection{Preparation and Testing Methods}

The materials were mixed according to ASTM C192 [14]. Coarser materials were first added to the mixer, 
Table 1 Composition of AAC.

\begin{tabular}{lcccc}
\hline Composition (\%) & Limestone & Cement & Sand & Perlite \\
\hline $\mathrm{SiO}_{2}$ & - & 21.02 & 85 & 71.02 \\
$\mathrm{Al}_{2} \mathrm{O}_{3}$ & 0.5 & 5.21 & 6.1 & 16.09 \\
$\mathrm{Fe}_{2} \mathrm{O}_{3}$ & 0.5 & 3.17 & 1.2 & 7.01 \\
$\mathrm{CaO}$ & 80 & 65.46 & 0.36 & 0.58 \\
$\mathrm{MgO}$ & 1 & 3.14 & 0.85 & 0.41 \\
$\mathrm{Na}$ & 0.2 & 0.14 & 1 & 0.90 \\
$\mathrm{~K}_{2} \mathrm{O}$ & 0.42 & 0.83 & 1 & 5.59 \\
\hline
\end{tabular}

Table 2 Properties of polypropylene fiber.

\begin{tabular}{ll}
\hline Properties & Data \\
\hline Specific gravity & 0.91 \\
Tensile strength (MPa) & $300-400$ \\
Modulus of elasticity (MPa) & 8,000 \\
Elongation at yield (\%) & 13 \\
Water absorption & 0 \\
Range of melting temperature $\left({ }^{\circ} \mathrm{C}\right)$ & $160-175$ \\
Evaporation point $\left({ }^{\circ} \mathrm{C}\right)$ & 341 \\
Burning temperature $\left({ }^{\circ} \mathrm{C}\right)$ & 460 \\
\hline
\end{tabular}

followed by approximately one-third of mixing water. Finer cementious materials and water were added to the running mixer in a gradual manner. Fiber was then added gradually to running mixer. The addition of PP fiber usually takes about 2 min. Then, the mixer continued without fibers continues for 3 min. After 3 min, the final mixing takes 2 min. In this studied, there were two different types of specimens used. The compressive and splitting tensile strength test, the specimens were casted in cylindrical molds, $102 \mathrm{~mm}$ in diameter and $204 \mathrm{~mm}$ in height. In two layers, each layer being consolidated using a vibrating table. The heat transfer and humidity test, the specimens were cast in standard commercial molds with dimensional of 300 $\mathrm{mm} \times 600 \mathrm{~mm} \times 75 \mathrm{~mm}$. In porosity test, the specimens were cut into cube shape with dimensions of $50 \mathrm{~mm} \times 50 \mathrm{~mm} \times 50 \mathrm{~mm}$. All AAC specimens were then kept in pressurize chamber at the pressure of 10-12 bars, temperature of $180-190{ }^{\circ} \mathrm{C}$ for $8 \mathrm{~h}$. The specimens were cut into standard sizes and required test amount by electric cutting device. The size accuracy was measured by vernier caliper instrument. The specimens were then placed in the oven at the temperature of $75{ }^{\circ} \mathrm{C}$ for $24 \mathrm{~h}$.
Compressive strength tests were carried out in accordance with ASTM C39 [15] and splitting tensile strength tests were done according to ASTM C496 [16] Flexural strength test were complied with ASTM C78/78M [17]. And, porosity test were conducted by vacuum saturation apparatus. Each data point reflects the four test results. The heat transfer and humidity of AAC house was tested according to Israngkura $\mathrm{Na}$ Ayudhya et al. [18]. Two experimental houses were built on open top floor of 63th building in College of Industrial Technology King Mongkut's University of Technology North Bangkok. The first experiment house was built with AAC-PP block whereas the second experimental house was built with AAC mixed without PP block (Non-AAC-PP). The dimensions of panel wall were $1,500 \mathrm{~mm} \times 1,800 \mathrm{~mm} \times 75 \mathrm{~mm}$. The total surface area of each side-wall was $2.7 \mathrm{~m}^{2}$. The surface of interior and exterior wall was refrained from mortar. The roof panel was clay tile beveled with $30^{\circ}$ lined with heat reflection aluminum foil. The roof panel was made by CPAC (Concrete Product and Aggregate Co., Ltd). The gypsum board was used as cover ceiling with the thickness of $1 \mathrm{~mm}$. The gypsum board acted as thermal barrier which can protect heat transfer through the attic to the experimental room. The plastic door $(1,500 \mathrm{~mm} \times 75 \mathrm{~mm} \times 35 \mathrm{~mm})$ was mounted on east side wall in each experimental house. Window glass $(500 \mathrm{~mm} \times 800 \mathrm{~mm} \times 6 \mathrm{~mm}$ ) was fitted at west side wall. The heat and humidity measurement instruments were located inside house (Figs. 1 and 2).

\section{Results and Discussion}

\subsection{Compressive Strength}

The compressive strength results of AAC-PP and Non-AAC-PP were shown in Table 3. The compressive strength increased with an increase in PP fiber content especially at $0.75 \%$ by volume where compressive strength of more than $2.88 \mathrm{~N} / \mathrm{mm}^{2}$ was found. The strength increased by $46.9 \%$ when compared with Non-AAC-PP specimen. However, PP fiber content increased from $0.75 \%$ to $1.0 \%, 1.5 \%$ and 


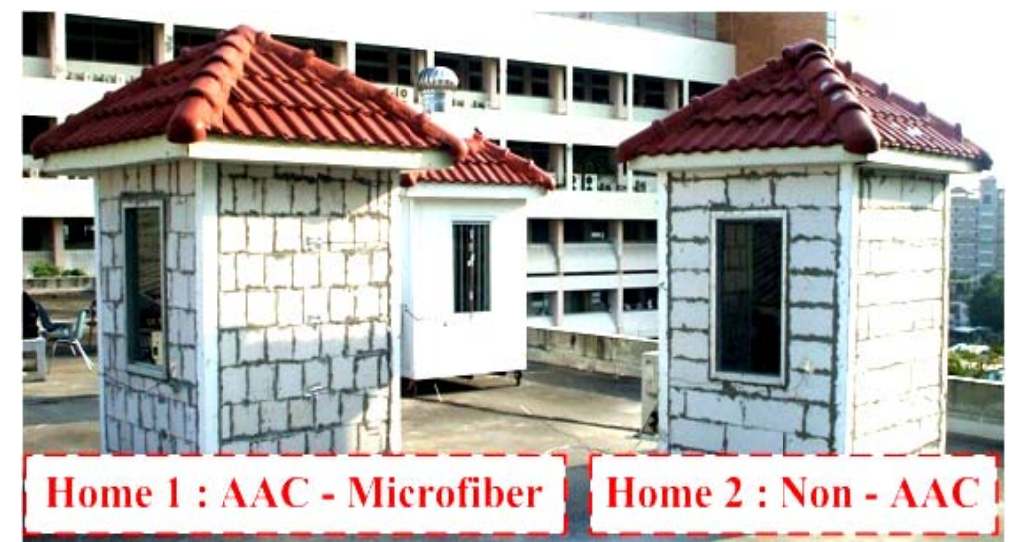

Fig. 1 Houses in experiment.
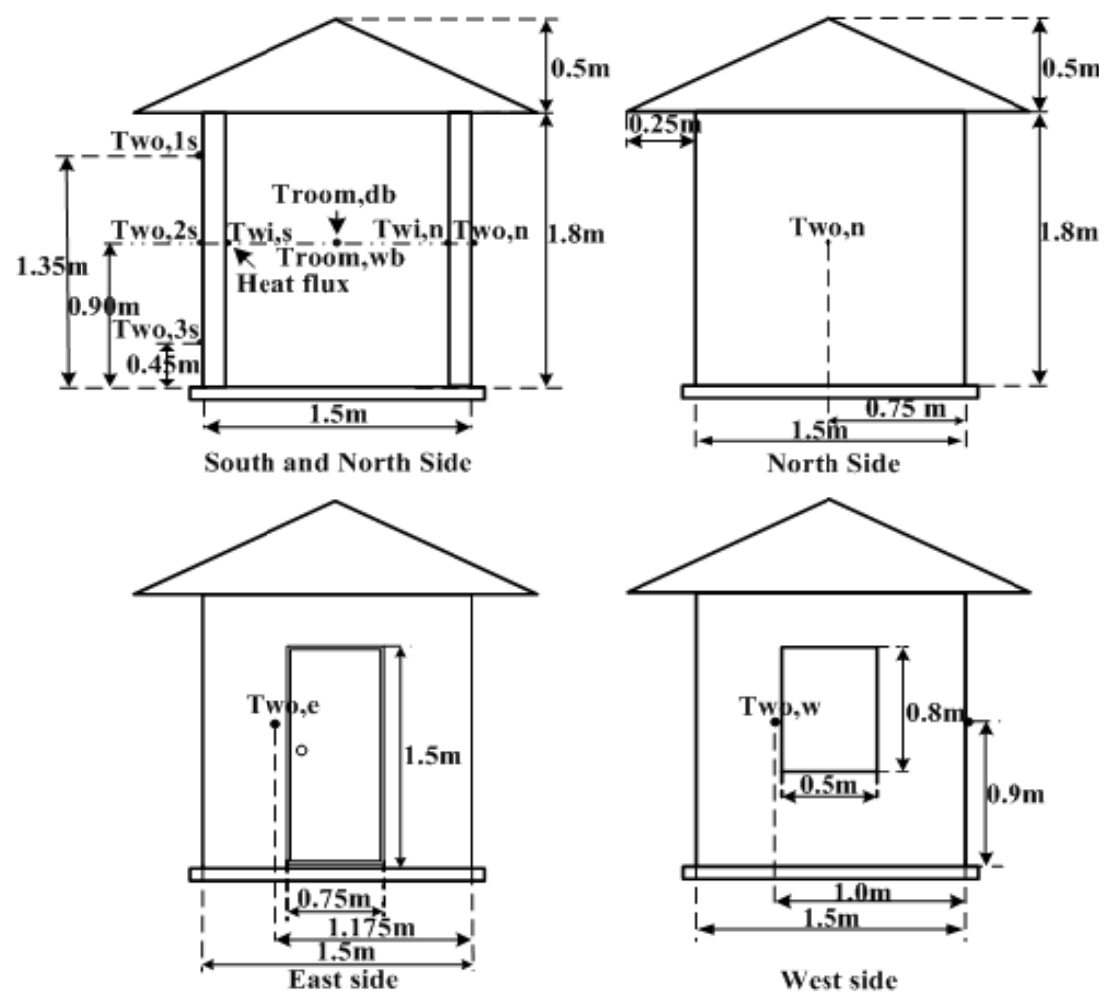

Fig. 2 Dimensions of the test houses and positions of temperatures measurement.

Table 3 Compressive and splitting strength test results.

\begin{tabular}{lllll}
\hline \multirow{2}{*}{ Mix (\% fiber) } & Porosity (\%) & \multicolumn{3}{c}{ AAC } \\
\cline { 3 - 5 } & & Compressive strength $\left(\mathrm{N} / \mathrm{mm}^{2}\right)$ & Flexural strength $\left(\mathrm{N} / \mathrm{mm}^{2}\right)$ & Splitting strength $\left(\mathrm{N} / \mathrm{mm}^{2}\right)$ \\
\hline 0 & 99 & 1.96 & 1.26 & 0.82 \\
0.5 & 98 & 2.04 & 1.28 & 0.81 \\
0.75 & 97 & 2.88 & 1.37 & 0.87 \\
1.0 & 95 & 2.51 & 1.25 & 0.81 \\
1.5 & 94 & 2.04 & 1.23 & 0.79 \\
2 & 93 & 1.92 & 1.20 & 0.78 \\
\hline
\end{tabular}

2\%, compressive strength decreased $14.7 \%, 41.2 \%$ and $50 \%$, respectively. This was due to amount and orientation of disperse of fiber which obstructed the voids. The interfacial bond between microfiber and 
disconnected air voids in AAC were weak. Furthermore, polypropylene fiber was chemically inert and hydrophobic, thus the potential for chemical bonding was limited [19]. Therefore, it appeared that an optimum compressive strength occurred at $0.75 \%$ microfiber dosage.

\subsection{Flexural Strength}

The flexural strength results of AAC-PP and Non-AAC-PP specimens were shown in Table 3. The result of experiment clearly showed that an increase in the amount of fiber content up to $0.75 \%$ by volume had increased the flexural strength. Similar to the results of compressive strength, an increasing flexural strength of specimens was found to relate to the decrease in porosity of concrete. The flexural strength of all specimens was in the range of $1.20-1.26 \mathrm{~N} / \mathrm{mm}^{2}$. However, the flexural strength decreased significantly when the amount of PP content increased above $0.75 \%$ by volume. Similar results were found by Qian [20]. Therefore, the flexural strength was at the highest of its strength when fiber content was at $0.75 \%$ by volume. It gained $8.7 \%$ strength compared to Non-AAC-PP specimens.

\subsection{Splitting Tensile Strength}

It was found from Table 3 that an average splitting strengths of AAC and AAC mixed with PP fiber at $0.5 \%, 0.75 \%, 1.0 \%, 1.5 \%$ and $2 \%$ were $0.82 \mathrm{~N} / \mathrm{mm}^{2}$,
$0.81 \mathrm{~N} / \mathrm{mm}^{2}, 0.87 \mathrm{~N} / \mathrm{mm}^{2}, 0.81 \mathrm{~N} / \mathrm{mm}^{2}, 0.79 \mathrm{~N} / \mathrm{mm}^{2}$ and $0.78 \mathrm{~N} / \mathrm{mm}^{2}$, respectively. The splitting tensile strength increased when the content of PP increased. However, the PP content did not show result in a significant improvement in the splitting tensile strength for the specimens. Similar results have been reported by other researchers [21].

\subsection{The Correlations between Porosity and Content of $P P$ and Porosity and Strength}

It has been found from Fig. 3 that the porosity of specimens decreased when the content of PP addition increased. The porosity of specimens rapidly decreased when the content of PP was above $1 \%$ by volume. Regard to the correlation between porosity and strength, the result showed in Fig. 4 that the compressive strength of specimens increased when the porosity of specimens increased up to $97 \%$ by volume. However, the compressive strength rapidly decreased when the porosity of specimens was higher than $97 \%$ by volume. It was further found that the compressive strength had significantly affects on the amount of PP addition more than flexural strength and splitting tensile strength. Therefore, it appeared that the optimum point of content of PP mixed was at $0.75 \%$ by volume for obtaining the ultimate strength. The flexural strength was at $1.37 \mathrm{~N} / \mathrm{mm}^{2}$ and the splitting tensile strength was at $0.87 \mathrm{~N} / \mathrm{mm}^{2}$.

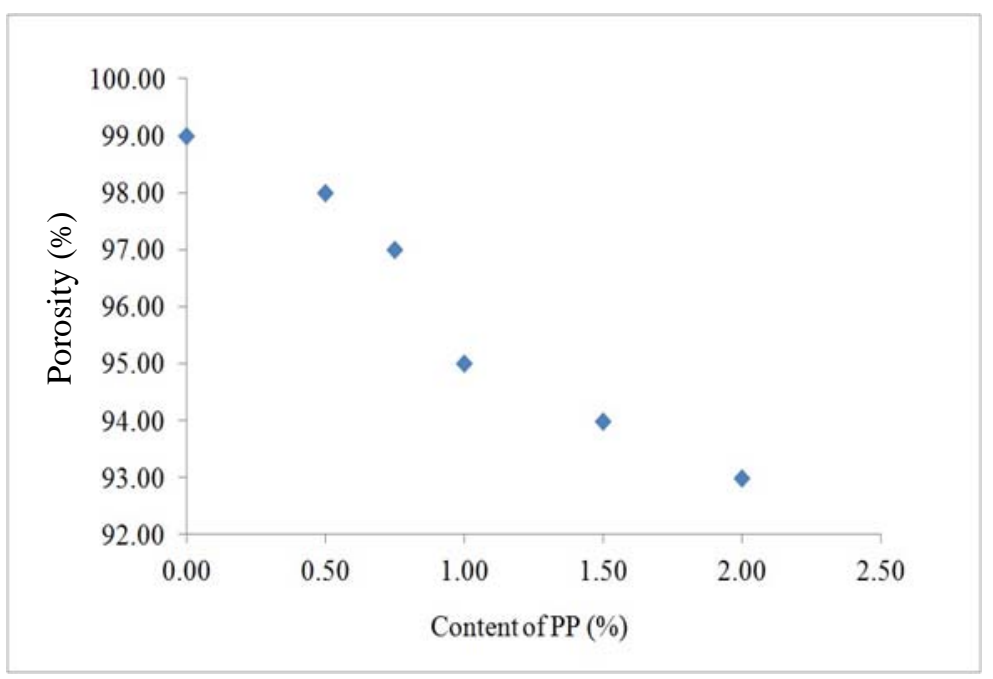

Fig. 3 The comparative between content of PP and porosity. 


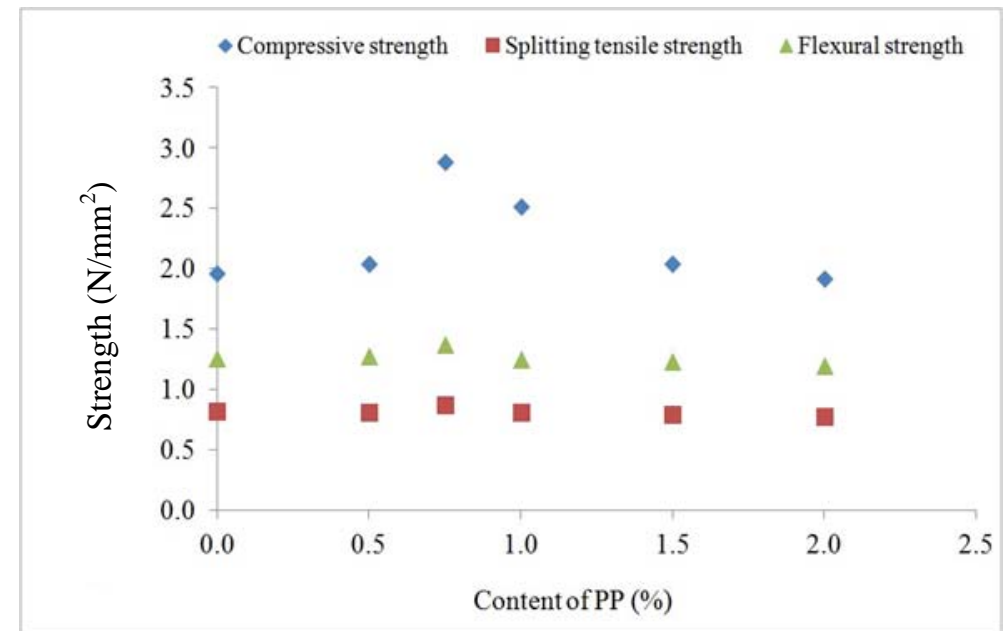

Fig. 4 The comparative between porosity and strengths.

\subsection{Heat Transfer and Humidity}

Based on strength and porosity test results in Table 3 and Fig. 4, respectively, it was found that the LWC (light weight concrete) decrease in thermal conductivity is due to the decreasing of concrete density. Similar results were found by Demirboga [22, 23] and Demirboga et al. and Blanco et al. [24, 25]. The thermal conductivity increases with the increase in the density of LWC. Therefore, the heat transfer and humidity test were then conducted on AAC-PP house mixed with $0.75 \%$ fiber addition. AAC-PP $(0.75 \%$ fiber addition) specimen gave the highest strengths with porosity of $97 \%$ by volume. The heat transfer and humidity results of AAC-PP and Non-AAC-PP house can be seen in Fig. 5. The graphical data showed the change in temperature of the environment (Tamb) and intensity of solar radiation from two experimental houses. During studied, the temperatures of surrounding experimental houses were in the range of 27-37 ${ }^{\circ} \mathrm{C}$ (6:00 a.m.-3:00 p.m.). Intensity of solar radiations varied from 12-671 W/m² (7:10 a.m.-12:10 p.m.). The speed of wind was in the range of 0.32-1.87 $\mathrm{m} / \mathrm{s}$.

The comparison results of room temperature (Troom), humidity (Rh, \%), environment temperature (Tamb) and air moisture (W) of two experimental houses were showed in Fig. 5. It was found that temperature inside AAC-PP house was lower than
Non-AAC-PP house about $0.5-3{ }^{\circ} \mathrm{C}$. It was further found that the temperature inside both experimental houses was also lower than environment temperature (Tamb). However, the indoor temperature of west wall surface of AAC-PP and Non-AAC-PP house was higher than the environment temperature (Fig. 6). This was due to the characteristic of thermal insulation of PP fiber which reduced accumulated heat on the layer of material and enhanced heat transfer of AAC-PP wall [26]. Therefore, it helps conservation energy from using air conditioner.

Figs. 7 and 8 showed the change in temperature of outside wall surface (Two), temperature of inside wall surface (Twi), north wall surface temperature (Tw, N) and west wall surface temperature (Tw, W) of two experimental houses. It was found that west wall of two experimental houses received solar radiation directly during the sun light. The temperature of outside west wall surface of two experimental houses was moderately the same. Whereas, the temperature outside west wall surface was higher than the environment temperature. This caused temperature outside north wall surface of two experimental houses was higher than the environment temperature. This was a result of reposition of the sun to the west. The north wall of both experimental houses received incidence solar radiation on the wall surface. However, it was found that the temperature inside both experimental 


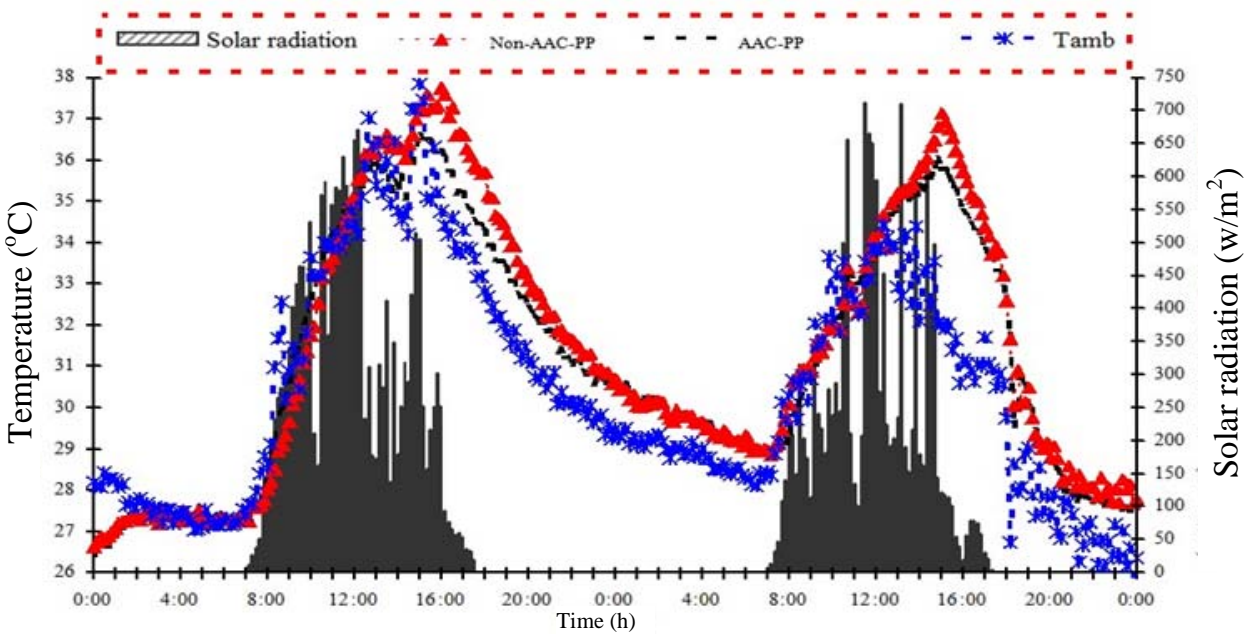

Fig. 5 Hourly variations of ambient temperature, solar radiation and indoor temperature of AAC-PP and Non-AAC-PP houses (December 15-16, 2010).

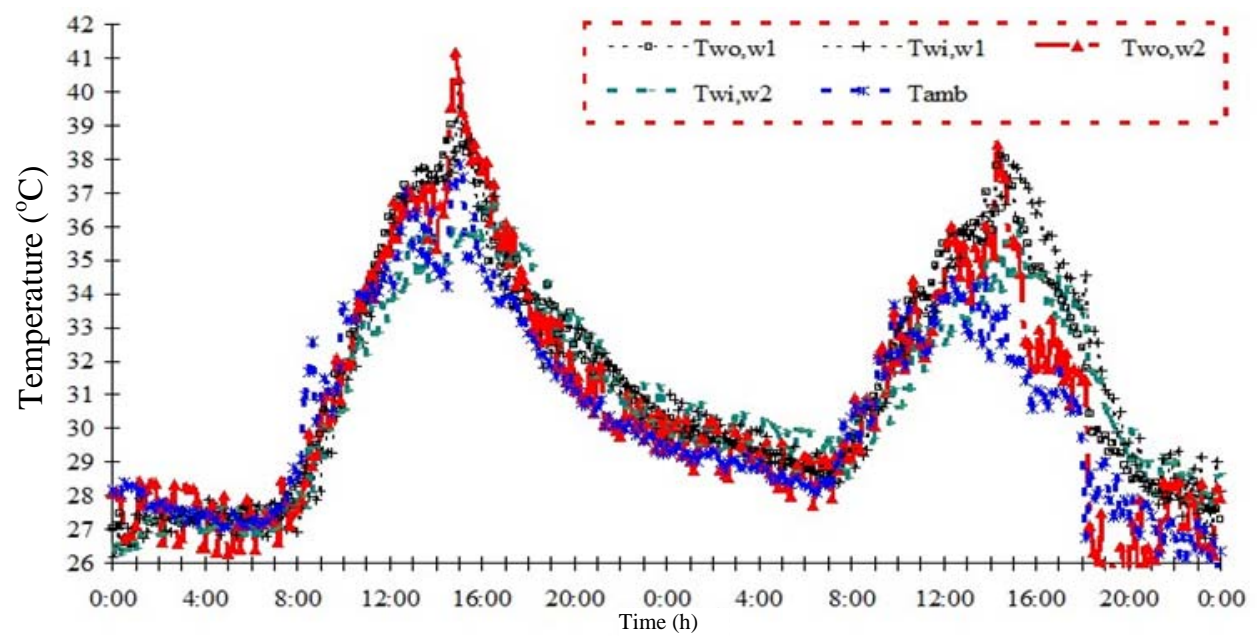

Fig. 6 Hourly variation of the ambient and west wall temperature of AAC-PP and Non-AAC-PP houses (December 15-16, 2010).

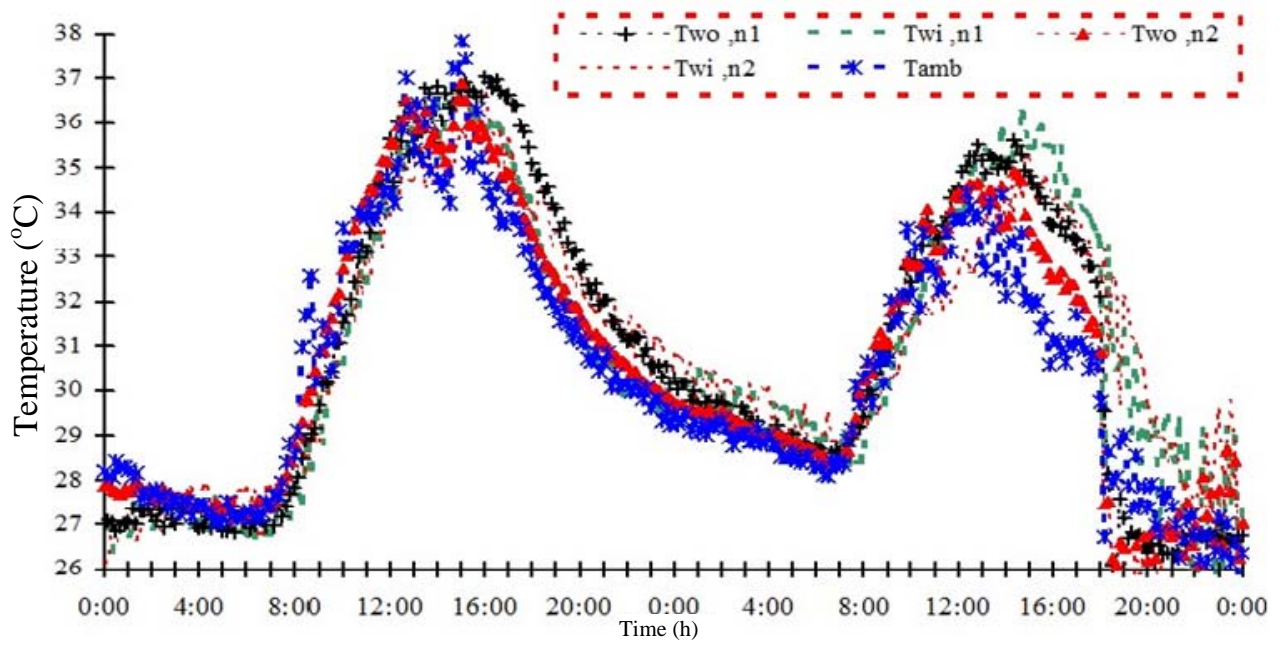

Fig. 7 Hourly variation of the ambient and north wall temperature of AAC-PP and Non-AAC-PP houses (December 15-16, 2010). 

Aerated Concrete Mixed Polypropylene Fiber under Climate of Bangkok

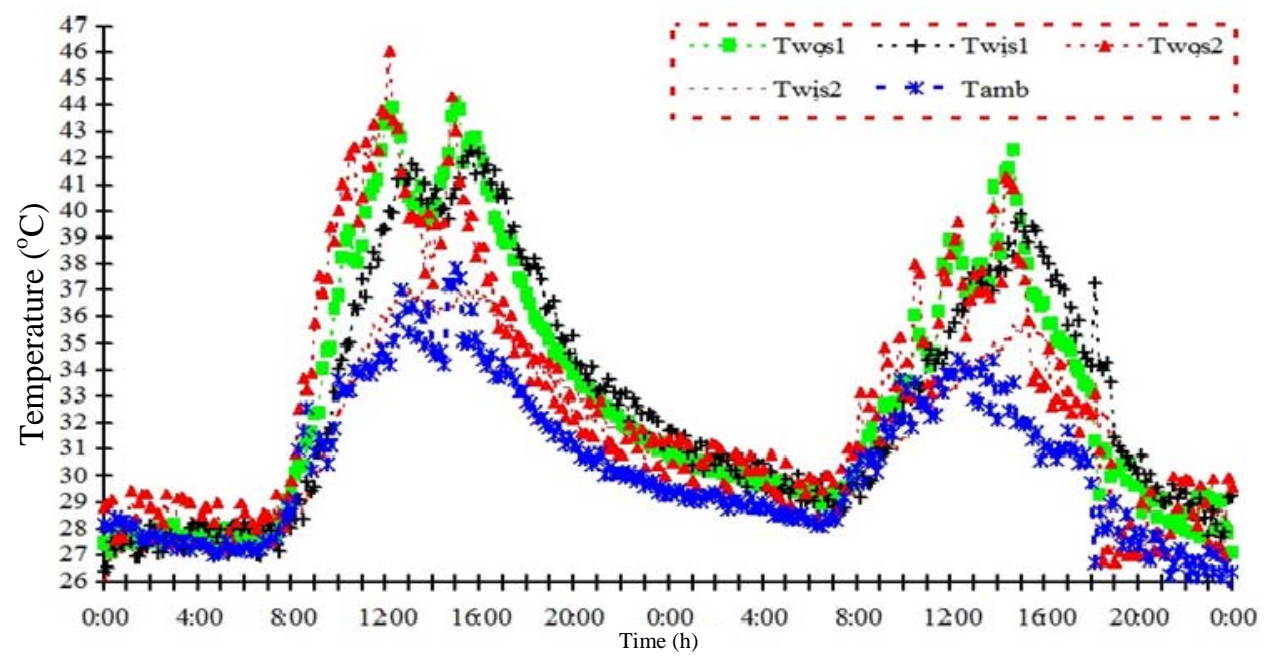

Fig. 8 Hourly variation of ambient and south walls temperature of AAC-PP and Non-AAC-PP houses (December 15-16, 2010).

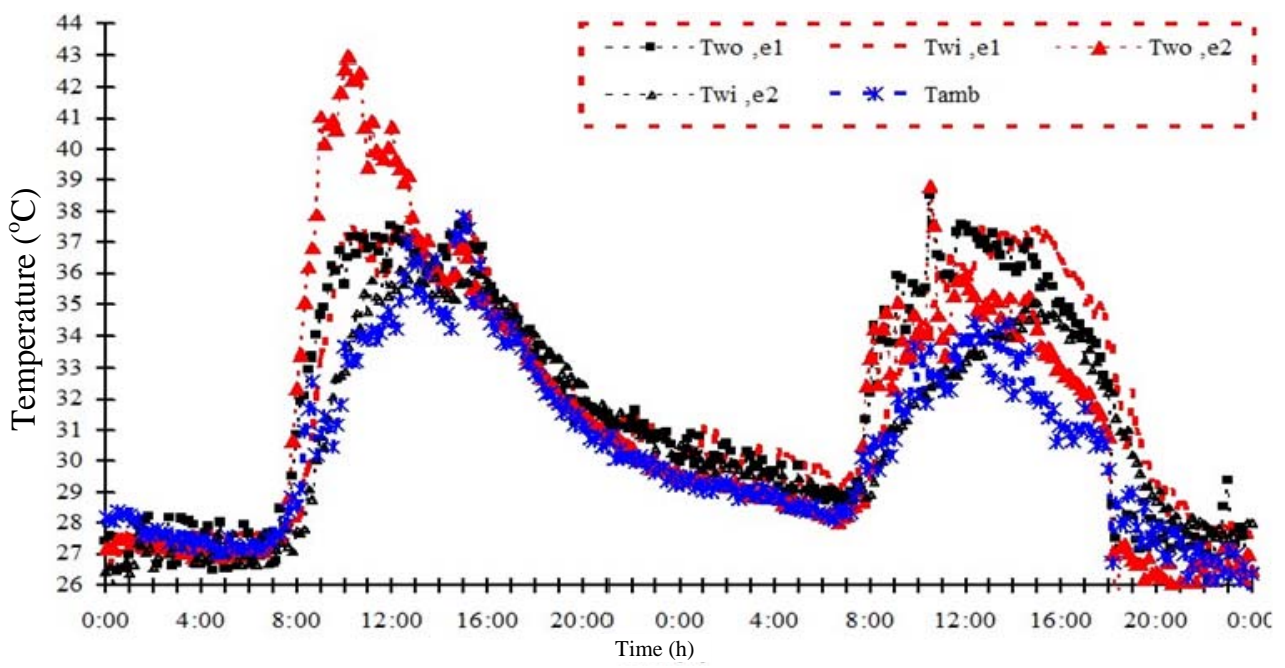

Fig. 9 Hourly variation of ambient and east walls temperature of AAC-PP and Non-AAC-PP houses (December 15-16, 2010).

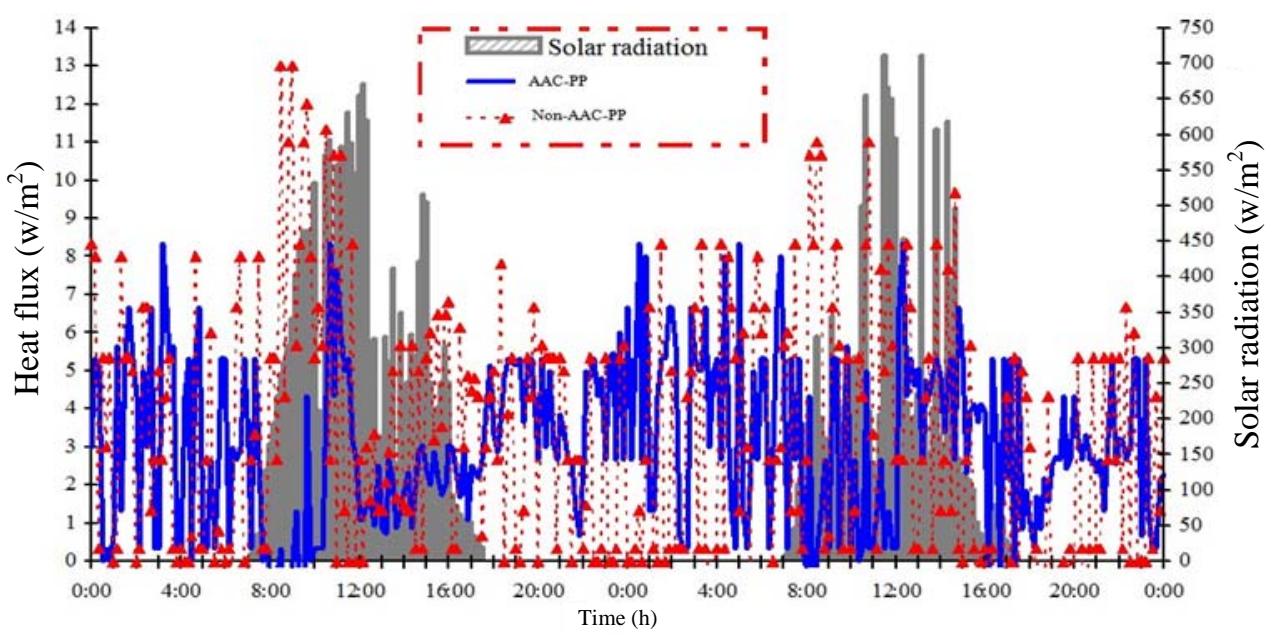

Fig. 10 Hourly variation of comparison for humidity and moisture content indoor of houses with AAC-PP and Non-AAC-PP (December 15-16, 2010). 
houses was almost equal to the environment temperature. The average of solar radiation illuminance was measured at $671 \mathrm{~W} / \mathrm{m}^{2}$. Regards to the temperature changed on the west wall surface ( $\mathrm{Tw}, \mathrm{W}$ ) (Fig. 6) and the east wall surface (Tw, E) of AAC-PP and Non-AAC-PP experimental house (Fig. 9), it was found that the temperature inside and outside of west and east wall surface of Non-AAC-PP house was higher than west and east wall surface of AAC-PP house. Furthermore, the inside and outside temperature of west and east wall surface of AAC-PP house was also higher than environment temperature during 6:00 a.m.-15:00 p.m.. Fig. 10 showed the results of study on humidity, moisture inside both experimental houses. An accumulated vapor in the air and other objects in the houses volatilized when obtained heat from outside and the environment increased. It was found that humidity and moisture of environment was higher than humidity and moisture air inside of both AAC-PP and Non-AAC-PP experimental houses. This was due to the rain. It increased the humidity of surrounding environment. This caused the humidity and moisture inside AAC-PP and Non-AAC-PP experimental house is high. However, the humidity and moisture inside of both experimental houses were almost similar. Regard to the change of the heat through the west wall surface of experimental houses, it was found that the amount of detected heat reduced by $38.46 \%$ in AAC-PP house when compared with Non-AAC-PP house.

\section{Conclusions}

Based on the experimental study conducted and the discussion, it can be concluded that the PP increased the compressive strength, flexural strength and splitting tensile strength. It was found that the ultimate strength was at $0.75 \%$ by volume of fiber dosage. However, fiber addition has an effect on compressive than flexural and splitting tensile strength. The fiber addition increased the strength of compressive, flexural and splitting tensile by $47 \%, 9 \%$ and $6 \%$, respectively. The behavior of AAC-PP specimens confirm generally accepted that with an increasing porosity the strength of the AAC-PP decreases. The strength of AAC-PP decreased with an increased fiber dosage. The performance of thermal insulation AAC-PP house was higher that Non-AAC-PP house. The humidity in AAC-PP house was lesser than Non-AAC-PP house. It reduced heat by $38.46 \%$ when compared with Non-AAC-PP house. It appeared that PP fiber could save energy. Therefore, composites materials have the potential to be applied for green construction materials areas and also may be an alternative material to the industrialization of the construction materials. However, great care of mixing fiber should be taken. The PP fiber in aqueous suspensions is subjected to flocculation effects that involve scales of dosage. Increases in flocculation also tend to reduce the strength of AAC. The fiber disorientation occurred when AAC-PP specimens were placed near high steam temperature nozzle in autoclaved chamber. This could also affect the strength of specimens.

\section{Acknowledgments}

The authors would like to give thanks to National Nanotechnology Center and Rajamagala University of Technology Krunthep for supporting on this research and thanks to student of College of Industrial Technology, King Mongkut's University of Technology North Bangkok who help to collect information for this research.

\section{References}

[1] V.P. de Freitas, V. Abrantes, P. Crausse, Moisture migration in building walls-Analysis of the interface phenomena, Journal of Building and Environment 31 (2) (1996) 99-108.

[2] Y. Ungkoon, P. Namprakai, N. Pratinthong, R. Sarachitti, A mathematical model on heat transfer and humidity in a house with aerated concrete wall under the climate of Thailand, KKU Engineering Journal 33 (4) (2006) 363-378. (in Thai)

[3] P. Chantawong, V. Vimanjan, C. Asasutjarit, J. Hirunlabh, J. Khedari, A. Orudee, et al., Field comparative study between light gray and lily white exterior surface color on indoor conditions of a house model under hot humid 
climate of Bangkok, The Journal of KMITNB 17 (3) (2007) 11-20. (in Thai)

[4] P. Chantawong, V. Vimanjan, W. Puangsombut, J. Hirunlabh, C. Asasutjarit, J. Khedari, Comparative study of effects on the thermal performance of exterior surface colour between of light grey and sky white colour of house model under hot humid climate of Bangkok, Engineering Journal of Siam University 9 (1) (2008) 31-40. (in Thai)

[5] D.M. Ogoli, Predicting indoor temperatures in closed building with high thermal mass, Journal of Energy and Buildings 35 (2003) 99-108.

[6] V. Cheng, E. Ng, B. Givoni, Effect of envelope colour and thermal mass on indoor temperature in hot humid climate, Journal Solar Energy 78 (2005) 528-534.

[7] P. Chantawong, V. Vimanjan, Study of the thermal performance of effects on exterior surface colour between of sky white and lily white colour of house model under hot humid climate of Bangkok, The Journal of Industrial Technology 4 (2) (2008) 68-76. (in Thai)

[8] K. Suksongyat, I. Chaisayun, A. Chankrapoe, P. Chantawong, V. Vimanjan, P. Namprakai, Economical comparative analysis between house built using red clay bricks wall and aerated concrete wall for heat transfers and thermal properties, The Journal of KMUITNB 17 (2) (2007) 34-42. (in Thai)

[9] Y. Ungkoon, P. Chantawong, Study of thermal performance and economic analysis of cost aerated concrete walls, The Journal of Applied Science 8 (2) (2009) 22-28. (in Thai)

[10] B. Israngkura Na Ayudhya, P. Chantawong, Y. Ungkoon, Study of hygrothermal performance of autoclaved aerated concrete mixed with sugar sediment and autoclaved aerated concrete walls under climate of Bangkok, Ladkrabang Engineering Journal 27 (4) (2010) 19-24. (in Thai)

[11] Specification for Portland Cement, British Standards, BS 12:1991, UK, 2001.

[12] Standard Specification for Portland Cement, Annual Book of ASTM Standards, ASTM C150-92, Vol. 1-4, Philadelphia, 2004.

[13] Autoclaved Aerated Lightweight Concrete Elements, Thai Industrial Standard, Bangkok, TIS 1505-2541, 2006.

[14] Standard Practice for Making and Curing Concrete Test Specimens in the Laboratory, Annual Book of ASTM Standards, ASTM C192-04, Vol. 1-4, Philadelphia, 2004.
[15] Standard Test Method for Compressive Strength of Cylindrical Concrete Standard Test Method for Compressive Strength of Cylindrical Concrete Specimens, Annual Book of ASTM Standards, ASTM C39-04, Vol. 1-4, Philadelphia, 2004.

[16] Standard Test Method for Splitting Tensile Strength of Cylindrical Concrete Specimens, Annual Book of ASTM Standards, ASTM C496/496M-04, Vol. 1-4, Philadelphia, 2004.

[17] Standard Test Method for Flexural Strength of Concrete (Using Simple Beam with Third-Point Loading), Annual Book of ASTM Standards, ASTM C78-02, Vol. 1-4, Philadelphia, 2002.

[18] B. Israngkura Na Ayudhya, P. Chantawong, Y. Ungkoon, Study of mechanical properties of autoclaved aerated lightweight concrete element containing microfiber, Journal of Science Ladkrabang 19 (2010) 59-68. (in Thai)

[19] D.S. Hannant, Fiber Cements and Fiber Concrete, Wiley, New York, USA, 1987.

[20] C.X. Qian, P. Stroeven, Development of hybrid polypropylene-steel fibre-reinforced concrete, Cement and Concrete Research 30 (2000) 63-69.

[21] B. Israngkura Na Ayudhya, P. Chantawong, Y. Ungkoon, Study of mechanical properties of autoclaved aerated concrete mixed with microfiber, The Journal of KMUITNB 21 (2) (2011) 266-271. (in Thai)

[22] R. Demirboga, Influence of mineral admixtures on thermal conductivity and compressive strength of mortar, Energy Building 35 (2003) 189-192.

[23] R. Demirboga, Thermal conductivity and compressive strength of concrete incorporation with mineral admixtures, Build Environment 2 (2007) 2467-2471.

[24] R. Demirboga, R. Gul, The effects of expanded perlite aggregate, silica fume, flyash on the thermal conductivity of lightweight concrete, Cement Concrete Research 33 (5) (2003) 723-727.

[25] F. Blanco, P. Garcia, P. Mateos, J. Ayala, Characteristic and properties of lightweight concrete manufactured with cenospheres, Cement Concrete Research 30 (2000) 1715-1722.

[26] S. Chirarattananon, P. Chaiwiwatworakul, S. Pattanasethanon, Daylight availability and models for global and diffuse horizontal illuminance and irradiance for Bangkok, Journal of Renewable Energy 26 (2002) 69-89. 